\title{
ANALISIS PROFITABILITAS USAHA PETERNAKAN AYAM KAMPUNG SUPER DI KABUPATEN JEMBER
}

\author{
Muhammad Ardi Wiranata', Joko Irsan Sanyoto², Hariadi Subagja ${ }^{2}$ \\ ${ }^{1}$ Manajemen Bisnis Unggas, Politeknik Negeri Jember \\ 2Jurusan Perternakan, Politeknik Negeri Jember \\ Email: muh.ardi.wiranat@gmail.com
}

\begin{abstract}
INTISARI
Penelitian ini bertujuan untuk mengetahui biaya manajemen, biaya bibit, produksi ayam, harga jual ayam terhadap tingkat keuntungan, nilai R/C ratio dan Return on Investmen (ROI) usaha peternakan ayam kampung super di Kabupaten Jember. Metode penelitian yang digunakan adalah metode survei dengan 18 responden peternak ayam kampung super di Kabupaten Jember. Data hasil penelitian diolah menggunakan analisis regresi linier berganda dan persamaan yang diperoleh sabagai berikut $Y=-1,90-0,35 X_{1}-1,22 X_{2}+0,23 X_{3}+2,26 X_{4}+$ $0,11 X_{5}$. Persamaan tersebut berarti setiap besaran tingkat keuntungan dipengaruhi oleh $X_{1}$ (biaya manajemen) sebesar -0,35, $\mathrm{X}_{2}$ (biaya pakan) sebesar -1,22, $\mathrm{X}_{3}$ (biaya bibit) sebesar 0,23, $\mathrm{X}_{4}$ (produksi ayam) sebesar 2,26, $\mathrm{X}_{5}$ (harga jual ayam) sebesar 0,11 . Tingkat keutungan usaha sebesar 16,6\%, nilai R/C ratio 1,18, dan ROI $16 \%$. Hasil penelitian menunjukkan bahwa faktor yang paling dominan pengaruhnya terhadap tingkat keuntungan yaitu biaya pakan, biaya manajemen dan produksi ayam. Profitabilitas dari penelitian ini 98\% telah diperthitungkan sedang faktor lain di luar penelitian ini sebesar $2 \%$.
\end{abstract}

Kata kunci: Profitabilitas, Ayam Kampung Super, Biaya

\begin{abstract}
This study aimed to determine the cost of management, day old chick cost, production, selling price to profit level, $R / C$ ratio and Return on Investmen (ROI) ayam kampung super in Jember. The research method used was survey with 18 respondents in Jember. The data result were analyzed using multiple linear regression analysis and the following equations were $Y=-1.90-0.35 X 1$ $1.22 X 2+0.23 X 3+2.26 X 4+0.11 X 5$. This equation means every level of profit level by $X 1$ (management cost) equal to -0.35, X2 (feed cost) equal to -1.22, X3 (seed cost) equal to 0.23, X4 (chicken production) equal to 2.26, X5 (chicken selling price) of 0.11. $R$ / C ratio was 1.18, and ROI was $16 \%$. The result of research showed that the most dominant factor influences to the profit level were feed cost, management cost and production. Profitability of this research 98\% have been considered while factors outside this study $2 \%$.
\end{abstract}

Keyword : Profitability, Kampung Super Chicken, Cost

\section{PENDAHULUAN}

Sektor peternakan selain berperan dalam bidang ekonomi, berperan juga dalam pemenuhan kebutuhan protein hewani. Kebutuhan masyarakat akan hasil ternak seperti daging, susu, dan telur semakin meningkat, seiring dengan pertumbuhan jumlah populasi penduduk Indonesia yang semakin bertambah, pendidikan yang semakin tinggi serta bertambahnya pengetahuan tentang pentingnya gizi.

Pembangunan pertanian pada sektor peternakan sebagai penunjang kebutuhan 
protein hewani yang merupakan kebutuhan dasar manusia perlu dimaksimalkan sehingga dapat memberi tambahan terhadap pendapatan peternak. Upaya untuk memaksimalkan kebutuhan protein dan permintaaan daging yang semakin tinggi sehingga peluang yang bias dikembangkan untuk meningkatkan produk ternak sebagai penghasil daging ayam kampung yaitu ayam kampung super.

Perkembangan usaha ayam kampung super di Kabupaten Jember kurang begitu maksimal, itu terbukti penyebaran peternak ayam kampung super hanya berada di beberapa kecamatan khususnya di daerah Kabupaten Jember bagian selatan. Banyak yang harus diketahui sebagai bahan evaluasi dalam usaha peternakan ayam kampung super dan perlu diketahui penyebab mengapa peternakan ayam kampung super di Kabupaten Jember kurang begitu berkembang.

Usaha peternakan ayam kampung super di Kabupaten Jember merupakan salah satu upaya peningkatan perekonomian peternak dengan harapan peternak mendapat keuntungan yang maksimal. Sebagian besar peternak belum mengetahui pengaruh biaya produksi yang meliputi aspek manajemen, pakan dan bibit terhadap keuntungan peternakan ayam kampung super. Atas dasar konseptual tersebut maka diperlukan penelitian tentang analisis profitabilitas usaha peternakan ayam kampung super di Kabupaten Jember.

Tujuan penelitian ini diantaranya untuk mengetahui peran faktor produksi seperti: biaya bibit, biaya pakan, dan biaya manajemen terhadap keuntungan, mengetahui tingkat keuntungaan yang didapat, mengetahui nilai $\mathrm{R} / \mathrm{C}$ ratio, dan ROI yang diperoleh peternak ayam kampung super di Kabupaten Jember.

\section{METODE PENELITIAN}

\section{Rancangan Penelitian}

Penelitian ini merupakan jenis penelitian yang menggunakan pendekatan deskriptif kuantitatif. Metode yang digunakan dalam pengambilan sampel yaitu survei.

\section{Populasi Penelitian dan Teknik Pengambilan Sampel}

Populasi dalam penelitian ini adalah peternakan ayam kampung super yang berada di Kabupaten Jember. Metode sampling yang digunakan dalam penelitian ini adalah purposive sampling teknik pengambilan sampel secara sengaja berdasarkan jumlah peternak dengan populasi 100 sampai 1.000 ekor, sudah beternak selama kurang lebih 5 periode atau 1 tahun. Total populasi yang sesuai dengan kriteria yang telah ditentukan sebanyak 18 peternak.

\section{Variabel Penelitian}

Variabel dalam penelitian meliputi variabel terikat (dependent) yaitu keuntungan, dan variabel tidak terikat (independent) yaitu: biaya manajemen, pembelian bibit, biaya pakan, jumlah produksi, dan harga jual. 


\section{Instrumen Penelitian}

Alat yang digunakan dalam pengumpulan data pada penelitian ini adalah kuisoner. Kuisoner yang dibuat untuk menggali data yang kemudian dilakukan analisis data pada peternakan ayam kampung super di Kabupaten Jember.

\section{Lokasi dan Waktu Penelitian}

Penelitian ini dilaksanakan selama 3 bulan, yaitu pada bulan November 2015 sampai Januari 2016 di Kabupaten Jember.

\section{Analisis Data}

\section{Biaya produksi}

Total biaya merupakan seluruh biaya yang digunakan dalam proses produksi dengan rumus sebagai berikut:

$$
\mathrm{A}=\mathrm{B}+\mathrm{C}+\mathrm{D}
$$

Keterangan:

$\mathrm{A}=$ Biaya produksi

$\mathrm{B}$ = Biaya manajemen

$\mathrm{C}$ = Biaya pakan

$\mathrm{D}$ = Biaya bibit

\section{Penerimaan}

Penerimaan merupakan semua pendapatan yang didapatkan dari hasil penjualan ayam.

$$
\mathrm{TR}=\mathrm{Pq} \times \mathrm{Q}
$$

Keterangan :

$\mathrm{TR}=$ Total Revenue atau penerimaan (Rp/tahun)

$\mathrm{Pq}=$ Price Quantity atau harga satuan produk (Rp/ekor)

$\mathrm{Q}=$ Quantity atau volume penjualan (ekor/tahun)

\section{Analisis keuntungan (profitabilitas)}

Profit atau keuntungan yaitu hasil laba yang diperoleh dari penerimaan dikurangi dengan total biaya. Nilai profitabilitas yaitu laba sebelum bunga dan pajak dibagi total aktiva dikalikan seratus persen.

\section{Analisis statistik}

Uji determinasi. Uji determinasi ditentukan oleh koefisien (R2) untuk menghitung seberapa besar variabel dependen (keuntungan). Variabel-variabel yang diteliti antara lain: biaya manajemen, biaya pakan, dan biaya bibit. Nilai R2 paling besar 1 dan paling kecil $0(0<\mathrm{R} 2<1)$. Bila R2 sama dengan 0 maka garis regresi tidak dapat digunakan untuk membuat ramalan variabel dependen, sebab variabel-variabel yang dimaksudkan kedalam persamaan regresi tidak mempunyai pengaruh varian variabel dependen. Semakin dekat R2 dengan 1, maka semakin tepat regresi untuk meramalkan variabel dependen, dan menunjukkan kondisi yang sebenarnya dalam penelitian.

\section{Analisis regresi linier berganda.}

Analisis regresi linear berganda diuji dengan menggunakan alat bantu Software Statistik Package Software System 16 (SPSS).

$R / C$ ratio. $R / C$ ratio dalam penelitian ini merupakan hasil dari perbandingan total peneriman dan total biaya. Apabila nilai dari $\mathrm{R} / \mathrm{C}>1$ maka usaha dinyatakan layak atau menguntungkan, apabila nilai $\mathrm{R} / \mathrm{C}=1$ maka usaha dinyatakan impas.

$$
\mathrm{R} / \mathrm{C} \text { ratio }=\mathrm{TR} / \mathrm{C}
$$


Keterangan :

TR $=$ Total Penerimaan

$\mathrm{TC}=$ Total biaya

Return on Investment (ROI). ROI mencerminkan kemampuan manajemen dalam mengatur aktiva-aktivanya seoptimal mungkin sehingga dicapai laba bersih yang diinginkan.

$$
\text { ROI }=\frac{\text { Keuntungan }}{\text { Biaya Investasi }} \times 100 \%
$$

\section{HASIL DAN PEMBAHASAN}

Analisis Statistik

Analisis statistik pada peternakan ayam kampung super di Kabupaten Jember yaitu menggunakan uji determinasi dan analisis regresi linier berganda.

\section{Uji determinasi}

Hasil dari analisis uji F digunakan untuk mengetahui apakah variabel independen berpengaruh secara bersama terhadap variabel dependen yaitu nilai signifikansinya **. Nilai R yang diperoleh sebesar 0,987 atau 98,7\%, yang menunjukkan terdapat pengaruh dari variabel independen terhadap variabel dependen sebesar 98,7\%, sedangkan 1,3\% dipengaruhi dari variabel lain.

\section{Analisis regresi linier berganda}

Hasil analisis regresi linier berganda profitabilitas peternakan ayam kampung super di Kabupaten Jember diperoleh persamaan regresi: $\mathrm{Y}=-1,905-0,35 \mathrm{X}_{1}-$ $1,22 X_{2}+0,23 X_{3}+2,26 X_{4}+0,11 X_{5}$

\section{Biaya Produksi}

Biaya produksi pada peternakan ayam kampung super di Kabupaten Jember terdapat 3 aspek yaitu biaya manajemen (biaya penyusutan kandang dan peralatan, biaya tenaga kerja, biaya vaksinasi, obat, vitamin, desinfektan (VOVD), dan biaya listrik), biaya pakan, dan biaya bibit.

\section{Biaya manajemen}

Usaha ayam kampung super di Kabupaten Jember meliputi biaya kandang dan peralatan, biaya tenaga kerja, biaya VOVD, dan biaya listrik, total dari keempat biaya tersebut dikelompokkan menjadi satu biaya manajemen yang dihitung selama 5 periode pemeliharaan. Biaya manajemen ayam kampung super di Kabupaten Jember yaitu sebesar Rp47.500.000,00 atau 11\% dari biaya total keseluruhan. Biaya manajemen yang dikeluarkan oleh peternak ayam kampung super di Kabupaten Jember tertinggi adalah untuk biaya tenaga kerja dan biaya VOVD.

Hasil dari biaya manajemen tersebut lebih kecil apabila dibandingkan dengan hasil penelitian Dewanti dan Sihombing (2012) bahwa besarnya biaya manajemen sebesar $15,75 \%$ pada analisis pendapatan usaha peternakan ayam buras. Selisih persentase biaya manajemen tersebut dikarenakan perbedaan manajemen biaya produksi, harga bahan baku yang digunakan, serta lokasi dan waktu pendirian usaha berpengaruh terhadap besar kecilnya biaya manajemen. 


\section{Biaya pakan}

Biaya pakan pada peternakan ayam kampung super di Kabupaten Jember menggunakan biaya dalam perhitungan selama 5 periode pemeliharaan. Biaya pakan pada peternak ayam kampung super di Kabupaten Jember yaitu sebesar Rp567.359.029,00 atau 64,6\%. Besarnya biaya pakan pada usaha peternakan ayam kampung super disebabkan karena belum adanya pakan khusus untuk ayam kampung pedaging, akibatnya sebagian peternak menggunakan pakan jadi ayam broiler, sehingga biaya pakan pada peternakan ayam kampung super di Kabupaten Jember relatif lebih tinggi.

Hasil dari biaya pakan yang dikeluarkan untuk beternak ayam kampung super relatif sama dengan pernyataan pada penelitian Dewanti dan Sihombing (2012) bahwa biaya pakan yang digunakan sebesar $76 \%$ dari total biaya produksi. Biaya pakan sangat mempengaruhi terhadap tingkat keuntungan karena persentase terbesar dalam suatu usaha peternakan adalah biaya pakan. Untuk itu perlu efisiensi biaya pakan agar mendapatkan keuntungan yang lebih tinggi.

Pakan ayam kampung super yang digunakan peternakan ada dua jenis yaitu pakan pabrikan dan pakan buatan sendiri. Sebagian besar peternak ayam kampung super menggunakan pakan pabrikan BR1 dan 511 yaitu pakan untuk ayam broiler sehingga biayanya tinggi, sedangkan beberapa peternak ada yang mencampur pakan sendiri untuk menekan biaya produksi dengan menggunakan beberapa bahan pakan yaitu konsentrat, jagung, bekatul, dan tepung ikan. Keuntungan pakan pabrikan lebih cepat dalam pertumbuhan ayam serta FCR lebih baik, namun biaya yang dikeluarkan lebih besar dibandingkan pakan buatan sendiri. Pakan buatan sendiri secara finansial lebih murah dan ekonomis, namun kandungan nutrisinya tidak terkontrol dengan baik, sehingga hasil produksinya lebih rendah dari pakan pabrikan.

\section{Biaya bibit}

Biaya bibit pada peternakan ayam kampung super di Kabupaten Jember menggunakan biaya dalam perhitungan selama 5 periode pemeliharaan. Biaya bibit pada peternak ayam kampung super di Kabupaten Jember yaitu sebesar Rp232.215.000,00 atau 26,1\%. Biaya bibit ayam kampung super di Kabupaten Jember berkisar harga Rp4.900,00 sampai Rp5.200,00 per ekornya, jadi perbedaan harga bibit ayam kampung tidak begitu besar dengan selisih sekitar Rp300,00. Bibit ayam kampung super berasal dari produsen lokal dan beberapa diantaranya dari CV Kuda Hitam Perkasa (Kediri), CV Sumber Rejeki Farm (Kediri), dan Jogja Farm (Yogyakarta).

\section{Total Biaya Produksi}

Total biaya produksi merupakan total dari biaya manajemen, biaya pakan, dan biaya bibit pada peternakan ayam kampung super di Kabupaten Jember selama 5 periode pemeliharaan. Total biaya produksi ayam kampung super di Kabupaten Jember sebesar 
Rp799.574.029,00 atau sebesar Rp18.475,00 ekor/periode. Hasil penelitian Dewanti dan Sihombing (2012) di Kecamatan Tegalombo Kabupaten Pacitan menunjukkan bahwa pada peternakan ayam buras dengan populasi 150 ekor biaya produksi yang dibutuhkan yaitu sebesar Rp3.251.267,00/periode atau Rp21.675,00/ekor/periode.

\section{Penerimaan}

\section{Jumlah produksi ayam}

Jumlah produksi ayam kampung super dihitung selama 1 tahun produksi atau selama 5 periode produksi, dan jumlah produksi ayam kampung super pada saat penelitian yaitu sebesar 43.278 ekor. Penjualan ayam kampung super berdasarkan ekor dengan acuan bobot badan ayam. Masing-masing peternak memiliki standar panen dengan umur yang telah ditentukan sesuai permintaan permintaan pasar. Rata-rata ayam kampung super dipelihara sekitar kurang lebih 2 bulan atau akan panen dikisaran bobot badan 0,6 sampai $1 \mathrm{~kg} / \mathrm{ekor}$ disesuaikan dengan target bobot badan yang diinginkan.

\section{Harga jual ayam}

Harga jual ayam kampung super di Kabupaten Jember mengalami perbedaan antara peternak satu dengan peternak yang lain. Harga rata-rata ayam kampung super sebesar Rp22.568,00/ekor. Perbedaan harga ayam antar peternak satu dengan yang lain dikarenakan bobot panen ayam per ekornya yang berbeda serta saluran pemasaran yang berbeda-beda.

\section{Total penerimaan}

Rata-rata penerimaan yang diperoleh selama satu tahun produksi atau 5 periode oleh peternak ayam kampung super di Kabupaten Jember yaitu sebesar Rp58.527.061,00/peternak. Total penerimaan tersebut lebih tinggi dibandingkan dengan hasil penelitian Hartono et al. (2013) yang menyatakan bahwa kinerja ekonomi usaha ayam sentul pedaging di Kabupaten Ciamis sebesar Rp42.726.125,00. Perbedaan penerimaan tersebut terdapat pada jumlah produksi yang berbeda-beda antar peternak satu dengan yang lainya dan perbedaan bobot panen ayam kampung super yang berbeda pula.

\section{Keuntungan dan Profitabilitas}

\section{Keuntungan}

Total keuntungan yang didapat selama 5 produksi oleh peternak ayam kampung super di Kabupaten Jember yaitu sebesar Rp157.102.481,00/tahun atau sebesar Rp3.630,00 per ekor. Keuntungan yang diperoleh tersebut lebih besar apabila dibandingkan dengan hasil penelitian Penggu et al. (2014) yang menunjukkan hasil bahwa keuntungan pada peternakan ayam kampung dengan populasi 524 ekor per tahun yaitu sebesar Rp1.430.241,00 atau sebesar Rp2.729,00 per ekornya. Tingginya keuntungan usaha peternakan ayam kampung super di Kabupaten Jember karena permintaan pasar yang tinggi. 


\section{Profitabilitas}

Angka profitabilitas atau tingkat keuntungan peternakan ayam kampung super di Kabupaten Jember yaitu sebesar 16,6\%. Tingkat keuntungan atau profitabilitas yang diperoleh tersebut relatif lebih kecil apabila dibandingkan dengan penelitian Pambudi et al. (2013) bahwa usaha peternakan ayam broiler besar tingkat keuntunganya yaitu sebesar 26\%. Selisih angka profitabilitas tersebut disebabkan jumlah populasi ternak yang dipelihara berbeda masing-masing peternak waktu penelitian yang berbeda mempengaruhi harga jual ayam, bibit, dan pakan ayam yang mempengaruhi keuntungan peternak ayam kampung super di Kabupaten Jember. Tingkat keuntungan usaha peternakan ayam kampung super di Kabupaten Jember bisa ditingkatkan dengan cara menurunkan biaya pakan yang terlalu tinggi.

\section{Analisis Kelayakan Usaha}

\section{R/C Ratio}

Rata-rata nilai $\mathrm{R} / \mathrm{C}$ ratio sebesar 1,18 yang berarti bahwa setiap 1 rupiah yang dikeluarkan menghasilkan 1,18 rupiah. Beberapa peternak yang diamati menunjukkan nilai R/C ratio tertinggi sebesar 1,28 dan nilai $\mathrm{R} / \mathrm{C}$ ratio terkecil sebesar 1,12.

$\mathrm{R} / \mathrm{C}$ ratio peternak ayam kampung super di Kabupaten Jember sebesar 1,18>1. Hal ini menunjukkan hasil yang menguntungkan yang berarti setiap peternak mengeluarkan 100 rupiah akan menghasilkan 118 rupiah. Usaha peternakan ayam kampung super akan dikatakan efisien apabila usaha ternak telah mampu menggunakan sumber dana yang dimiliki sebaik mungkin untuk melengkapi kebutuhan usahanya (Hartono, et al. 2013).

\section{Return on Investment (ROI)}

Hasil analisis ROI pada peternakan ayam kampung super selama 5 periode produksi menunjukkan bahwa nilai rata-rata ROI sebesar 16\%. Hasil analisis ROI ini menunjukkan sejauh mana kemampuan usaha ayam kampung super untuk pengembalian modal dibandingkan dengan suku bunga Bank Pinjaman Bank Rakyat Indonesia KUR (Kredit Usaha Rakyat).

Pengembalian atas investasi bertujuan untuk mengetahui perbandingan antara pemasukan (income) per tahun terhadap dana investasi yang memberikan indikasi profitabilitas suatu investasi (Suharto, 2002). Hasil perhitungan ROI menunjukkan bahwa peternak ayam kampung super di Kabupaten Jember sebesar 16\%. Hasil tersebut lebih besar dari suku bunga Deposito Bank BRI sebesar 6,63\%, sehingga uang yang digunakan untuk usaha peternakan ayam kampung super memberi keuntungan yang menjanjikan daripada uang hanya disimpan di Bank.

\section{KESIMPULAN DAN SARAN}

\section{Kesimpulan}

Persentase biaya manajemen cukup baik yaitu sebesar $11,03 \%$ dari total biaya produksi. Persentase biaya pakan pada peternak ayam kampung super merupakan 
biaya tertinggi dari biaya-biaya yang lain yaitu sebesar $64,61 \%$ dari total biaya produksi. Tingkat keuntungan peternak ayam kampung super di Kabupaten Jember relatif kurang dibandingkan dengan usaha ayam broiler yaitu sebesar 16,6\%. R/C ratio peternakan ayam kampung super di Kabupaten Jember relatif sama dengan usaha peternakan ayam kampung yaitu sebesar 1,18. ROI peternak ayam kampung super di Kabupaten Jember cukup baik dibandingkan suku bunga Bank BRI pada pinjaman KUR yaitu sebesar 16\%.

\section{Saran}

Peningkatan profitabilitas dapat dilakukan dengan menurunkan biaya pakan melalui perbaikan kualitas pakan serta dan memperbaiki tata pemberian pakan agar tidak tercecer.

\section{DAFTAR PUSTAKA}

Dewanti R. dan G. Sihombing. 2012. Analisis pendapatan usaha peternakan ayam buras (studi kasus di Kecamatan Tegalombo, Kabupaten Pacitan). Buletin Peternakan. 36(1):48-56.

Hartono, E.F., N.N. Hidayat, dan Roesdiyanto. 2013. Kinerja ekonomi usaha ayam sentul di Kabupaten Ciamis. Jurnal Ilmiah Peternakan. 1(3):865-873.

Pambudi, T.R., O.E. Djatmiko, dan N.N. Hidayat, 2013. Analisis keuntungan dan rentabilitas usaha ayam niaga pedaging (Studi Kasus Pada Kemitraan Ismaya Unggas Makmur Di Kabupaten Kebumen). Jurnal Peternakan.

Penggu, P., N.M. Santa, A. Makalew, dan P.O.V. Waleleng. 2014. Hubungan biaya produksi dengan pendapatan usaha ternak ayam kampung (studi kasus di desa Pungkol Kecamatan Tatapaan,
Kabupaten Minahasa Selatan). Jurnal Zootek. 34(edisi khusus):67-75.

Suharto, I. 2002. Studi Kelayakan Proyek Industri. Erlangga. 